\title{
Potential use of PET and PP as partial replacement of sand in structural concrete
}

\author{
Uso potencial de PET e PP como substituição \\ parcial de areia em concreto estrutural
}

\author{
Priscila Marques Correa ${ }^{1}$, Diego Guimarães ${ }^{2}$, \\ Ruth Marlene Campomanes Santana ${ }^{1}$, Ângela Gaio Graeff ${ }^{2}$
}

\begin{abstract}
${ }^{1}$ Universidade Federal do Rio Grande do Sul, Programa de Pós-Graduação em Engenharia de Minas, Metalúrgica e Materiais, Avenida Bento Gonçalves 9500, Agronomia, CEP: 91509-900, Porto Alegre, RS, Brasil.

${ }^{2}$ Universidade Federal do Rio Grande do Sul, Programa de Pós-Graduação em Engenharia Civil, Construção e Infraestrutura; Avenida Bento Gonçalves 9500, Agronomia, CEP: 91509-900, Porto Alegre, RS, Brasil.
\end{abstract}

e-mail: priengenheira@gmail.com, ruth.santana@ufrgs.br, dguimaraes81@yahoo.com.br, angela.graeff@ufrgs.br

\begin{abstract}
The use of polymeric residues in the civil construction has been the target of many studies aiming to reduce the volume of post-consumer plastics in the environment. This work focuses on the viability to use polyethylene terephthalate (PET) and polypropylene (PP) as partial replacement to sand in concrete. PET and PP flakes from post-consumer packings were used as light aggregate to partially replace, individually, $10 \%$ in volume of sand. The effect of adding these polymers was investigated in terms of physical, mechanical, durability and morphological properties of the concrete. Physical properties were measured in terms of water absorption, voids content and specific mass. Mechanical properties were measured in terms of compressive strength and elasticity modulus. Durability properties were measured in terms of capillarity water absorption and electrical indication of the concrete to resist to chloride ion penetration. MEV and EDS were used to carry out morphological analysis. DSC curves were carried out to evaluate thermal properties of the polymeric flakes. Contact anlge test was also performed. The partial addition of PET and PP polymers reduced the compressive strength by $20 \%$, whilst the reduction of the elasticity modulus was $16 \%$ for PET samples, and almost insignificant for PP samples. The durability results show that the polymers contributed to increase the resistance of the samples to chloride penetration by 15\% and 57\%, for PET and PP samples, respectively; however, there was an increase in the voids content and water absorption. In the morphological test it is possible to observe a lower interfacial adhesion between PP and the cementions paste in comparison to PET.
\end{abstract}

Keywords: Post-consumer plastic, PET, PP, concrete with residues

\section{RESUMO}

O uso de resíduos poliméricos na construção civil tem sido alvo de muitos estudos com o objetivo de reduzir o volume de plásticos pós-consumo no meio ambiente. Este trabalho concentra-se na viabilidade do uso de politereftalato de etileno (PET) e polipropileno (PP) como substituição parcial da areia no concreto. Os flocos de PET e PP pós-consumo foram utilizados como agregado leve para substituir parcialmente em $10 \%$ o volume de areia. $\mathrm{O}$ efeito da adição desses polímeros foi investigado em termos de propriedades físicas, mecânicas, de durabilidade e morfológicas do concreto. As propriedades físicas foram a absorção de água, teor de vazios e massa específica. As propriedades mecânicas das amostras foram medidas em termos de resistência à compressão e módulo de elasticidade. A durabilidade foi avaliada em termos de absorção de água por capilaridade e indicação elétrica do concreto para resistir à penetração de íons cloretos. A análise morfológica foi realizada pelo MEV e EDS. Curvas de DSC foram utilizadas para avaliar as propriedades térmicas dos flocos. O-teste de ângulo de contato também foi realizado. A adição parcial de polímeros de PET e PP reduziu a resistência à compressão em $20 \%$, enquanto a redução do módulo de elasticidade foi de $16 \%$ para as amostras de PET e quase insignificante para as amostras de PP. Os resultados de durabilidade mostram que os polímeros contribuíram para aumentar a resistência das amostras à penetração de cloretos em $15 \%$ e $57 \%$, para amostras de PET e PP, respectivamente, no entanto, houve um aumento no teor de vazios e na absorção de 
água. No ensaio de morfologia é possível observar uma menor adesão interfacial entre o PP e a massa cimenticia em comparação ao PET.

Palavras-chave: Plástico pós-consumo, PET, PP, concreto com resíduos.

\section{INTRODUCTION}

One ton of concrete is produced annually for each inhabitant of the world, which highlights the environmental impact caused by the production of concrete [1]. In Brazil, the production of concrete is responsible for 15 to $50 \%$ of the natural resources' consumption, which leads to a yearly consumption of approximately 220 million tons of sand only for concrete production $[2,3]$.

The high cost and shortage of sand in some areas of Brazil has turned the recycling of polymeric residues into an interesting option to replace the natural resource. This is especially because polymeric commodities are largely produced and used [1,2] so the amount of recyclable post-consumer plastics is abundant all over the world. The use of polymeric residues by the civil construction may be an effective alternative to reduce the environmental impact caused by polymer discarding and to the development of greener materials.

Many authors studied the use of polymeric residues, such as polyethylene terephthalate (PET) [1-5] and polypropylene (PP) $[1,6,7]$ processed as fibres and flakes for concrete production.

The author FRIGIONE [2] studied the substitution of 5\% of fine aggregates derived from PET bottle milling. The results show that the incorporation of PET reduces the compressive and tensile strength of the concrete and presents a lower modulus of elasticity.

ALBANO et al. [8] investigated the mechanical behavior of concrete with the incorporation of PET residue particles in which the replacement contents (in volume) were $10 \%$ and $20 \%$ and the particle size of PET ranged from $0.26 \mathrm{~cm}$ and $1.14 \mathrm{~cm}$. The results show a decrease in the compressive strength, tensile strength and modulus of elasticity of the concrete mixture.

The use of polymers as fibres for concrete has been the target of many studies in the last years [9-11]. However, the fibre production process requires extra processing stages such as wiring and extrusion, which leads to the high cost of the final product $[12,13]$.

Previous studies based on the partial replacement of sand by PET show that there is a decrease on the compressive and flexural strength and an increase on the water absorption of the samples with the inclusion of polymers $[14,15]$. Studies based on the use of polymeric flakes in concrete are rare when compared to the use of fibres. On this context, this research aims to evaluate the use of PET and PP as flakes, obtained from post-consumer food packaging, as partial replacement of sand, in terms of physical, mechanical, durability and morphological properties of structural concrete. Thermal and contact angle tests were also performed in PET and PP samples to contribute to the analyses of the concrete properties.

\section{MATERIALS AND EXPERIMENTAL PROGRAM}

\subsection{Materials}

Three mixture proportions were studied in this research: one mixture proportion as reference without residues, and two mixes with polypropylene (PP) and polyethylene terephthalate (PET) flakes residues, added separately, as partial replacement of sand in the amount of $10 \%$ by volume. The mixture proportions are presented in Table 1. Reference mixture was chosen due to the fact that it is a mixture commonly used in regular civil construction and complies with the minimum requirements for structural concrete according to Brazilian standard for concrete design procedures, ABNT NBR 6118 [16]. The use of flakes in the amount of $10 \%$ by volume was based on a previous study with PET and PP flakes in different contents [14] that evaluated the gains in terms of mechanical behavior and environmental viability. RAHMANI et al. [17] also showed that a concrete with $10 \%$ fine aggregates volume replaced by PET particles has the same results than concrete without PET, which justifies the choice of the $10 \%$ content in this study. 
Table 1: Mixture proportions.

\begin{tabular}{|c|c|c|c|c|c|}
\hline Sample & $\begin{array}{l}\text { Cement } \\
\left(\mathrm{kg} / \mathrm{m}^{3}\right)\end{array}$ & $\begin{array}{l}\text { Fine aggregate } \\
\left(\mathrm{kg} / \mathrm{m}^{3}\right)\end{array}$ & $\begin{array}{l}\text { Coarse aggregate } \\
\left(\mathrm{kg} / \mathrm{m}^{3}\right)\end{array}$ & $\begin{array}{l}\text { PET and PP } \\
\text { post-consumer } \\
\text { flakes }\left(\mathrm{kg} / \mathrm{m}^{3}\right)\end{array}$ & Water/cement \\
\hline Reference & 400 & 800 & 1200 & - & 0.52 \\
\hline PET & 400 & 720 & 1200 & 41.34 & 0.52 \\
\hline PP & 400 & 720 & 1200 & 27.56 & 0.52 \\
\hline
\end{tabular}

High-early-compressive-strength Portland cement was used in the research. The cement is classified as type V according to NBR 16697 [18] and ASTM C150 (2019), with resistance class of $46.8 \mathrm{MPa}$ at 28 days, surface area of $1.71 \mathrm{~m}^{2} / \mathrm{g}$ and specific mass of $3.16 \mathrm{~g} / \mathrm{cm}^{3}$. The sand and gravel used in the research are of quartz and basaltic origin, respectively. The polymeric aggregates were obtained from post-consumer food packages and were ground in a knife mill.

Table 2 shows a summary of the physical properties of the natural and polymeric aggregates in terms of specific mass and specific surface area, the latter obtained by the BET (Brunauer, Emmett, Teller) method.

Table 2: Physical properties of aggregates.

\begin{tabular}{|c|c|c|}
\hline Aggregates & Specific mass $\left(\mathrm{g} / \mathrm{cm}^{3}\right)$ & Specific surface area $\left(\mathrm{m}^{2} / \mathrm{kg}\right)$ \\
\hline Coarse & 2.88 & - \\
\hline Fine & 2.60 & 2.60 \\
\hline PET & 1.38 & 3.35 \\
\hline $\mathrm{PP}$ & 0.90 & 2.88 \\
\hline
\end{tabular}

The gradation curves for sand, PET and PP are shown in Figure 1

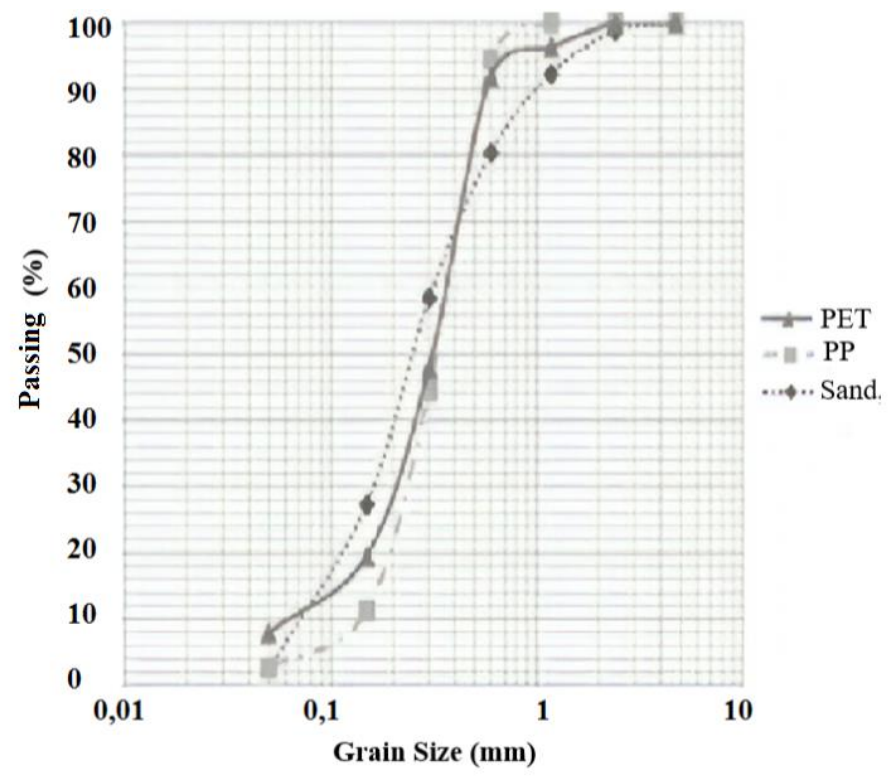

Figure 1: Gradation curves of aggregates.

\subsection{Research method}

The research was developed aiming to initially characterize the polymers in terms of thermal analysis and contact angle. The concretes with post-consumer polymers were analysed in terms of physical, mechanical, durability and morphological properties. Thermal analysis with DSC (Differential Scanning Calorimeter) curves was carried out in the polymers to identify a possible degradation of polymers. The contact angle analysis was performed to measure the wettability of the polymers by a liquid. 
The physical properties of hardened concrete were the void content, specific mass and water absorption, while the slump test was carried out for fresh concrete. The mechanical properties were the compressive strength and modulus of elasticity. The durability properties were the water absorption by capillarity and resistance to chloride ion penetration. The Morphological analysis was carried out by SEM (Scanning Electron Microscopy) and DES (Dispersive Energy Spectroscopy) tests.

The equipment used to perform DSC test is from TA Instruments, Q20 model. PP specimens were subjected to a heating ramp from $25^{\circ} \mathrm{C}$ to $200^{\circ} \mathrm{C}$, whilst the PET specimens were subjected from $25^{\circ} \mathrm{C}$ to $300^{\circ} \mathrm{C}$. The heating rate was $10^{\circ} \mathrm{C} / \mathrm{min}$ in inert $\mathrm{N}_{2}$.

The contact angle measurements were performed on a Rame-Hart model goniometer 100-00, according to ASTM D 724 [19]. Software OCA 20 was used to determine the contact angle. The liquid used for the sessile drop test was deionized water with a $\mathrm{pH}$ of approximately 7.0. For each sample, 10 drops were made and each drop was photographed for further analysis

Cylinders measuring $100 \mathrm{~mm}$ in diameter and $200 \mathrm{~mm}$ in height were cast to measure the specific mass, water absorption and void content (physical properties), and also for mechanical properties. To evaluate the behavior in terms of durability, cylinders measuring $100 \mathrm{~mm}$ in diameter and $50 \mathrm{~mm}$ in height were used, which were cut from $200 \mathrm{~mm}$ in height cylinders. The casting procedure for all specimens followed ABNT NBR 5738 [20], corresponding to the ASTM C192 (2016). Specimens were compacted in two layers using a vibrating table. Three specimens were cast for each mixture proportion and each property to be evaluated (exception applies for specimens used for physical properties, since the same three specimens were used to measure all the properties within this group). The tests were performed at 28 and 90 days aiming to verify whether there is any property change that indicate degradation of the polymers after being exposed to the alkaline environment of the concrete.

The tests for physical, mechanical and durability properties of concretes with polymers were performed according to the Brazilian Association for Technical Standardization (Associação Brasileira de Normas Técnicas - ABNT), except the test to determine the concrete resistance to chloride ion penetration, which was carried out according to the ASTM C1202 [21]. Table 3 describes the main differences between the Brazilian and the correspondent ASTM Standard, since ASTMs are most commonly used and accessed worldwide in comparison to the Brazilians standards

Table 3: Main differences between ABNT and ASTM standards used in the research.

\begin{tabular}{c|c|c|c|c}
\hline Properties & Test & ABNT & $\begin{array}{c}\text { Corresponding } \\
\text { ASTM standard }\end{array}$ & $\begin{array}{c}\text { Difference between } \\
\text { Standards }\end{array}$ \\
\hline Physical & $\begin{array}{c}\text { Specific mass, water ab- } \\
\text { sorption and void content }\end{array}$ & NBR 9778 [22] & $\begin{array}{c}\text { ASTM C642 } \\
(2013)\end{array}$ & Procedure of testing \\
\cline { 2 - 5 } & Slump test & NBR NM 67 [23] & $\begin{array}{c}\text { ASTM C143 } \\
(2010)\end{array}$ & No difference \\
\hline Mechanical & Compressive strength & NBR 5739 [24] & ASTM C39 (2009) & $\begin{array}{c}\text { Speed loading of 0.45 MPa/s } \\
\text { for ABNT and 0.25 MPa/s for } \\
\text { ASTM }\end{array}$ \\
\cline { 2 - 5 } & $\begin{array}{c}\text { Static modulus of elastici- } \\
\text { ty }\end{array}$ & NBR 8522 [25] & $\begin{array}{c}\text { ASTM C469 } \\
(2014)\end{array}$ & $\begin{array}{c}\text { Elastic behaviour counted } \\
\text { until 30\% of the ultimate } \\
\text { stress for NBR and 40\% for } \\
\text { ASTM }\end{array}$ \\
\hline Durability & $\begin{array}{c}\text { Water absorption by cap- } \\
\text { illarity }\end{array}$ & NBR 9779 [26] & $\begin{array}{c}\text { ASTM } \\
\text { C1585(2013) }\end{array}$ & $\begin{array}{c}\text { Procedure of testing and test- } \\
\text { ing time }\end{array}$ \\
\hline
\end{tabular}

For the morphological analysis, the instrument used in this study was a standard Scanning Electron Microscope (SEM) Philips model XL30, and the test was performed in small samples of concrete (measuring approximately $3 \mathrm{~cm}$ wide), which were obtained from former cylinder specimens. The analysis was carried out especially at the interface between the polymer and the cementitious paste. 


\section{RESULTS AND DISCUSSIONS}

\subsection{Thermal properties of polymers}

This test aims to measure the possible hydrolytic degradation of PET and PP in an alkaline environment, which can lead to durability and mechanical problems of concrete in case the degradation-will be confirmed. Figure 2 shows the DSC thermal curves of PET and PP samples before (PET B and PP B) and after (PET A and PP A) 90 days of concrete curing.
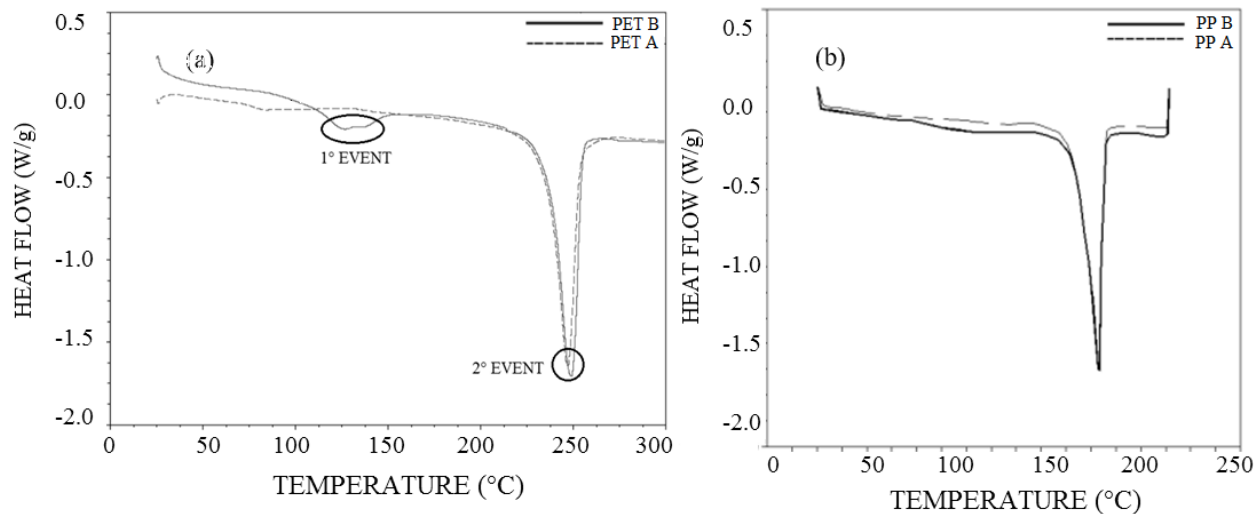

Figure 2: Thermal curves of DSC of the samples: (a) PET and (b) PP before and after 90 days of concrete curing.

For PET sample, in Figure 2(a) it can be observed two endothermic events, the first at $80-100^{\circ} \mathrm{C}$ interval, that can be attribute to the fusion process from hydrated crystals, probably the calcium hydrate. The interface formed with a cementitious matrix and this alkaline medium can favor the hydrolytic degradation of PET [27, 28 ] and the second at $250^{\circ} \mathrm{C}$, due to fusion temperature of PET. PET B sample does not present the first event, probably because many hydration reactions have not occurred yet. PET A sample presented 2 events after 90 days, which may be an indication of the formation of crystals, increasing the alkalinity of the matrix, and probably causing to PET the beginning of an alkaline hydrolytic degradation after being in contact to cementitious mass for all this period. Similar results were also observed by another author [29]. In the case of PP, it can be observed in Figure 2(b) that there were no changes in the fusion peak format when PP was added to the cement matrix. This behaviour may be an indication that PP is inert to the alkaline environment.

Some authors noted that PET degradation in the alkaline environment is clearer observed after 150 days of contact to this environment [30,31], which may lead to the rapid strength decrease of concrete, due to PET hydrolysis in the alkaline environment, thus causing higher void contents and reduction of durability and mechanical properties. ROUHOLLAH et al. [32] and AZAD et al. [33] also concluded that PET fiber degrades in alkaline environment, even though PET is resistant to weak acids.

\subsection{Contact angle}

Figure 3 shows the images of water droplets on the surface of PET and PP samples. It is observed that the PP samples are more hydrophobic than the PET samples due to the smaller water droplet spread of PP sample on the surface of the sample when compared to the droplet shape on the surface of the PET sample, shown in Figure 3(a). The higher droplet spreading observed in PET substrate is attributed to the higher polarity of its chemical structure when compared to PP, which only presents $\mathrm{C}-\mathrm{H}$ bonds (apolar). 
(a)

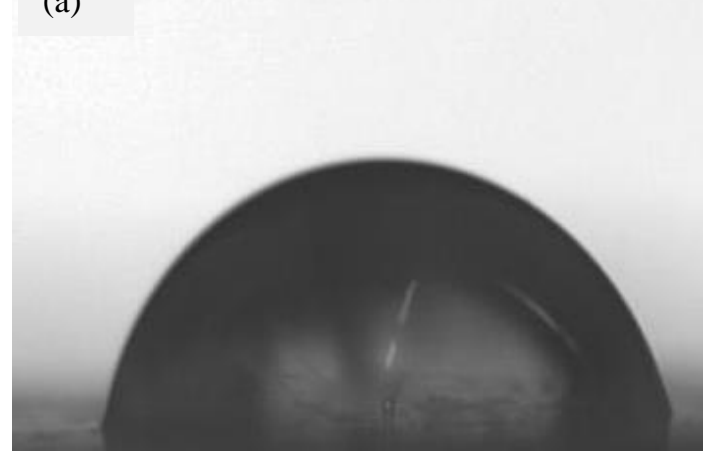

(b)

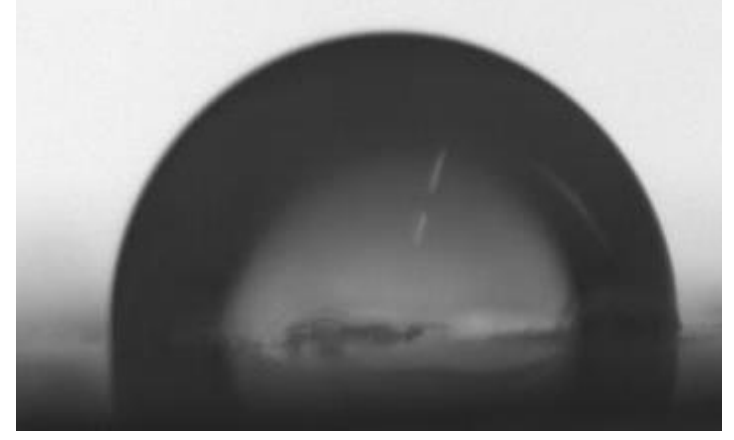

Figure 3: Water droplets on polymeric substrate: a) PET and b) PP

Table 4 shows that the contact angle of both samples differ from each other. These results resemble those of STROBEL et al. [34], whose contact angles for the PET sample were 70 . WANKE et al. [35] evaluated the contact angle of PP samples before applying a surface treatment, and the result was a contact angle of $90^{\circ}$, close to the results shown in Table 9, thus presenting a hydrophobic characteristic.

Table 4: Contact angle of PET and PP.

\begin{tabular}{l|l}
\hline Sample & Contact angle $\left(^{\circ}\right)$ \\
\hline PET & $68.8 \pm 0.78$ \\
\hline PP & $94.1 \pm 0.83$ \\
\hline
\end{tabular}

\subsection{Physical properties}

The results of the physical properties in terms of water absorption, void content and specific mass of the hardened concrete (average and standard deviation), evaluated at 28 and 90 days of curing, are shown in Table 5. The table also presents the results for the slump test of fresh concrete.

Table 5: Physical properties of concrete

\begin{tabular}{|c|c|c|c|c|c|c|}
\hline & \multicolumn{2}{|c|}{ Reference } & \multicolumn{2}{|c|}{ PET } & \multicolumn{2}{|c|}{ PP } \\
\hline & 28 days & 90 days & 28 days & 90 days & 28 days & 90 days \\
\hline $\begin{array}{c}\text { Water } \\
\text { absorption }(\%)\end{array}$ & $2.90 \pm 1.10$ & $2.50 \pm 0.97$ & $5.40 \pm 1.60$ & $5.70 \pm 1.63$ & $7.40 \pm 0.70$ & $7.10 \pm 0.60$ \\
\hline $\begin{array}{c}\text { Void contente } \\
(\%)\end{array}$ & $8.93 \pm 1.47$ & $7.11 \pm 1.33$ & $11.2 \pm 1.16$ & $12.58 \pm 0.71$ & $15.62 \pm 1.36$ & $15.34 \pm 1.21$ \\
\hline $\begin{array}{c}\text { Specific mass } \\
\left(\mathrm{g} / \mathrm{cm}^{3}\right)\end{array}$ & $2.32 \pm 0.21$ & $2.39 \pm 0.32$ & $2.29 \pm 0.19$ & $2.33 \pm 0.24$ & $2.25 \pm 0.18$ & $2.29 \pm 0.21$ \\
\hline \multicolumn{7}{|c|}{ Slump (mm) } \\
\hline \multicolumn{2}{|c|}{ Reference: 100} & \multicolumn{3}{|c|}{ PET: 85} & \multicolumn{2}{|c|}{ PP: 125} \\
\hline
\end{tabular}

The addition of PP to fresh concrete increased the workability of the concrete probably due to the hydrophobic characteristic of PP, which repels water from its surface. Opposite behavior was observed when PET was added to concrete, probably due to its hygroscopic characteristic [14].

BATAYNEH et al. [36] investigated the effect of adding plastics (20\% as sand replacement) into fresh concrete. The slump test results show a $25 \%$ drop in the workability compared to the reference mixture. The authors concluded that this effect is due to the shape and surface area of the polymer flakes. This may also be the reason for the differences between concrete with PET and PP in the slump test results of this study.

As expected, there is a reduction on the water absorption and void content as ageing occurs due to cement hydration. PP and PET samples have higher water absorption and void content when compared to refe- 
rence mixture, even though the specimens with PET presented lower void content in comparison to PP specimens. This behaviour is probably due to the polar chemical structure of PET, which creates a better interaction between the polymer and the cementitious mass [14] even though the specific surface area of PET is higher than PP. The increase in the water absorption and void content for PET mixture, and also partially for $\mathrm{PP}$, is believed to be caused by the fact that the flakes have a non-spherical geometry in comparison to sand, which may contribute to the entrapment of air during mixture.

The reduction of the specific mass of concrete due to polymer addition is due to the following factors: firstly, the lower specific mass of the polymers when compared to natural sand, and secondly, to the increase of the void content as described previously. Similar behaviour was also observed in other studies [37-40].

\subsection{Mechanical properties}

Table 6 shows the results (average and standard deviation) for compressive strength and modulus of elasticity at 28 and 90 days

Table 6: Results of compressive strength and modulus of elasticity

\begin{tabular}{cllllll}
\cline { 2 - 6 } & \multicolumn{2}{c}{ Reference } & \multicolumn{2}{c}{ PET } & PP & \\
\cline { 2 - 6 } & $\mathbf{2 8}$ days & $\mathbf{9 0}$ days & $\mathbf{2 8}$ days & $\mathbf{9 0}$ days & $\mathbf{2 8}$ days & $\mathbf{9 0}$ days \\
\hline $\begin{array}{c}\text { Compressive Strength } \\
(\mathrm{MPa})\end{array}$ & $36.46 \pm 0.42$ & $42.47 \pm 0.99$ & $28.85 \pm 1.38$ & $33.23 \pm 1.47$ & $28.29 \pm 0.19$ & $34.33 \pm 0.14$ \\
\hline $\begin{array}{c}\text { Modulus of Elasticity } \\
(\mathrm{GPa})\end{array}$ & $33.35 \pm 0.07$ & $31.64 \pm 2.19$ & $26.11 \pm 0.01$ & $26.59 \pm 1.41$ & $33.65 \pm 0.19$ & $33.52 \pm 0.31$ \\
\hline
\end{tabular}

As expected, the results show a decrease on the values of the compressive strength as the post-consumer polymers are added to the mixture. This behaviour complies with other similar studies [26, 28]. The authors observed that the reduction on the compressive strength of concrete is due to the lower specific mass and strength of the residues.

Other authors observed that the reduction on the compressive strength when polymers are added to the concrete may also be due to the increase of the void content due to the porous interface observed between the cementitious matrix and the polymeric flakes [41, 42] and to the lower bond between cementitious matrix and the polymers when compared to conventional fine aggregate [17]. It can also be observed a slight increase in the compressive strength from 28 to 90 days, which is expected due to ageing of concrete.

For the results of the elasticity modulus, it can be observed a reduction on the values for PET samples when compared to reference mixture, probably due to the lower modulus of elasticity $(2,76-4,14 \mathrm{GPa})$ and lower specific mass of the polymer $1,38 \mathrm{~g} / \mathrm{cm}^{3}[43,44]$. This reduction on the elasticity modulus was also observed in other studies [16, 33, 45]. On the other hand, PP mixture proportion presented values of modulus similar to reference concrete. In comparison to PET, PP is a more crystalline polymer [42] which leads to an increase in the ductility of the concrete. It is believed that the lower modulus of elasticity of the polymers influences more the reduction on the modulus of elasticity of concrete than the lower specific gravity of polymers. The values of modulus of elasticity were similar at 28 and 90 days, as expected.

Figure 4 shows the images of the polymer flakes obtained through the Optical microscope with polarized light with image analyzer Carl Zeiss Axioscope A1 e Hotstage Linkam (T95; LNP) where it is possible to observe that the PP surface is less rough than PET. 

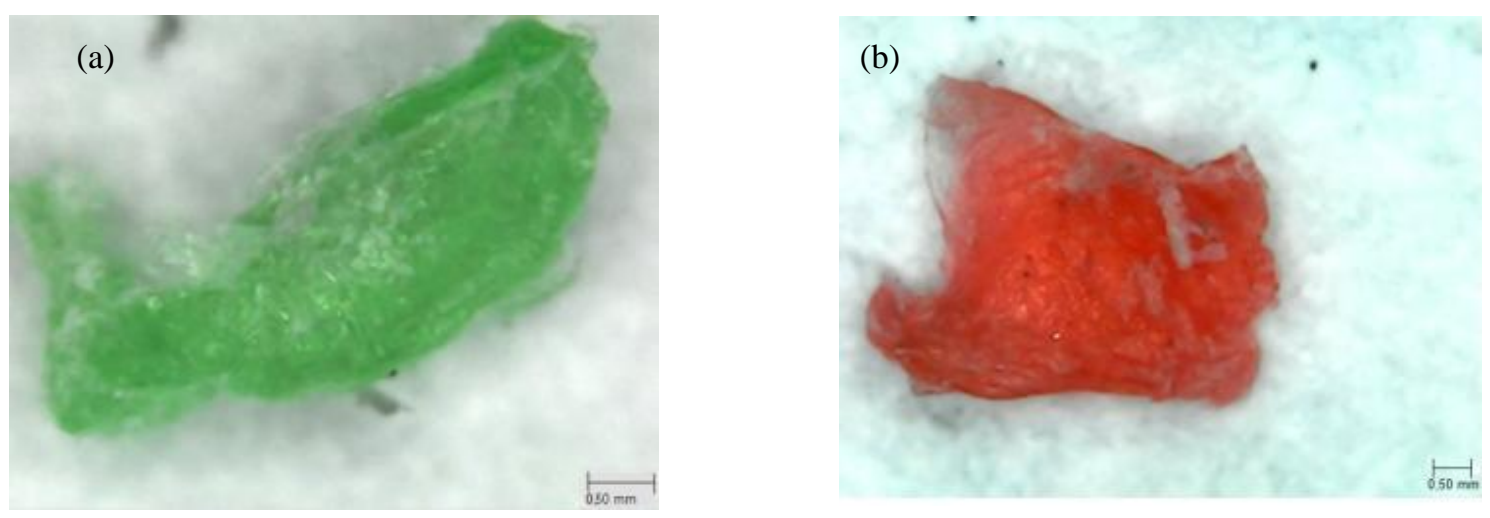

Figure 4: Images of cementitious matrix fracture surface with: a) PET and b) PP post-consumer flakes.

\subsection{Durability properties}

Tables 7 shows the results of capillary absorption and electric passing charge (average and standard deviation) for reference, PP and PET specimens at the age of 28 and 90 days.

Table 7: Capillary absorption and electric passing charge

\begin{tabular}{|c|c|c|c|c|c|c|}
\hline & \multicolumn{2}{|c|}{ Reference } & \multirow{2}{*}{$\begin{array}{r}\text { PET } \\
28 \text { days }\end{array}$} & \multicolumn{3}{|c|}{ PP } \\
\hline & 28 days & 90 days & & 90 days & 28 days & 90 days \\
\hline \multicolumn{7}{|c|}{ Capillary absorption } \\
\hline$\left(\mathrm{g} / \mathrm{cm}^{2}\right)$ & $0.54 \pm 0.28$ & $0.50 \pm 0.32$ & $0.44 \pm 0.39$ & $0.31 \pm 0.18$ & $0.54 \pm 0.17$ & $0.52 \pm 0.31$ \\
\hline \multicolumn{7}{|c|}{ Electric charge } \\
\hline$(\mathrm{kC})$ & $7.78 \pm 1.02$ & $6.92 \pm 0.98$ & $6.77 \pm 0.52$ & $5.89 \pm 0.48$ & $3.24 \pm 0.86$ & $2.98 \pm 0.79$ \\
\hline
\end{tabular}

For the capillary absorption test, PP and reference specimens presented similar results, both higher than PET specimens. This is probably due to the fact that PP does not bond efficiently to the cementitious mass. Moreover, the results also suggest that the pores of the cementitious mass are probably to be connected among them, which contributes to the water penetration through the capillary pores. For PET specimens the reduction on the water capillary absorption is probably due to a better packing of the materials and the stronger bond of the polymer to the cementitious paste, which can be observed by the SEM analysis, described in item 3.5 .

For the electric passing charge results, the addition of polymeric materials reduced the amount of electric charge in the concrete, when compared to reference samples. This behavior occurs because the polymers have the effect of reducing the load passing into the concrete. It can be noted that the addition of PP contributed to a higher electric resistance than PET, which is probably because the flakes may be acting as a barrier due to the polar characteristic of the polymer, thus making the flow of chlorides more difficult [29], as shown in the schematic figure 5 . 

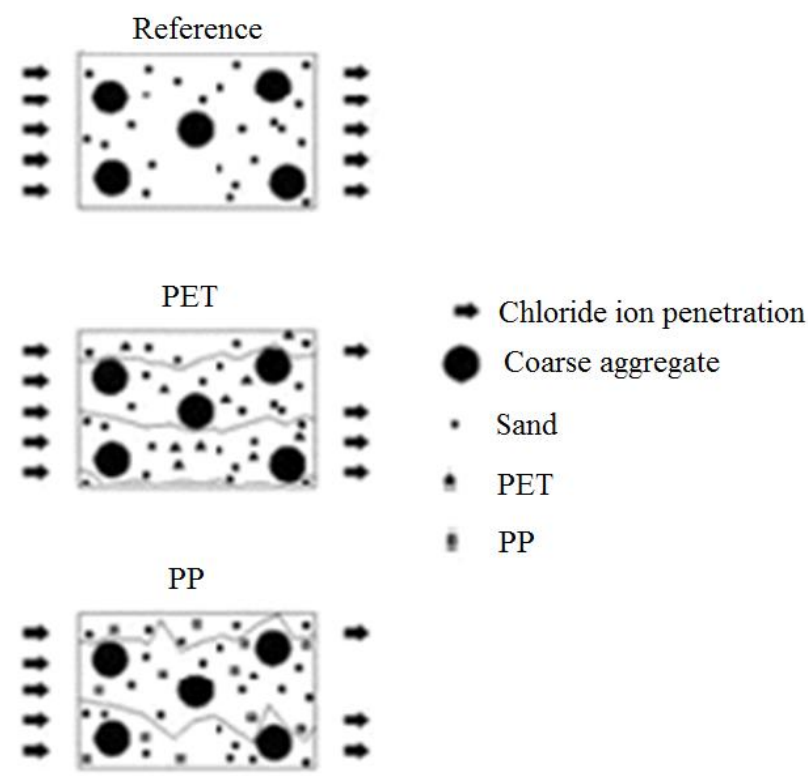

Figure 5: Proposed mechanism of chloride ion penetration into the concrete mixtures.

It is important to mention that the test proposed by ASTM C1202 [21] is an empirical test that gives only an indication of the concrete resistance to chloride ion penetration. The test is used mainly for comparison purposes and the results need to be careful analysed since the temperatures during test approached $60^{\circ} \mathrm{C}$ and may have influenced the results. Ideally, the determination of the chloride diffusion coefficient would be the best alternative.

\subsection{Morphological analysis}

The analysis by dispersive energy spectroscopy (DES) was evaluated to determine the chemical composition of the samples, mainly in the polymer interface and the cement paste. Samples obtained from each of the three mixtures, measuring $2 \mathrm{~cm}$ in diameter, were analyzed using a SEM Jeol LV5800 equipped with DES Thermo Noran. The results of the analysis using SEM and DES are shown in Figure 6 and Table 8. Figure 6(a) presents the SEM images of the surface of concrete sample containing PET, where a rough surface of the polymer can be noted, indicating a good adhesion between PET and the cementitious mass. The DES analysis carried out at PET shows the presence of possible deposition of calcium hydroxide after 90 days of curing favoured by the alkaline environment due to hydration reactions.
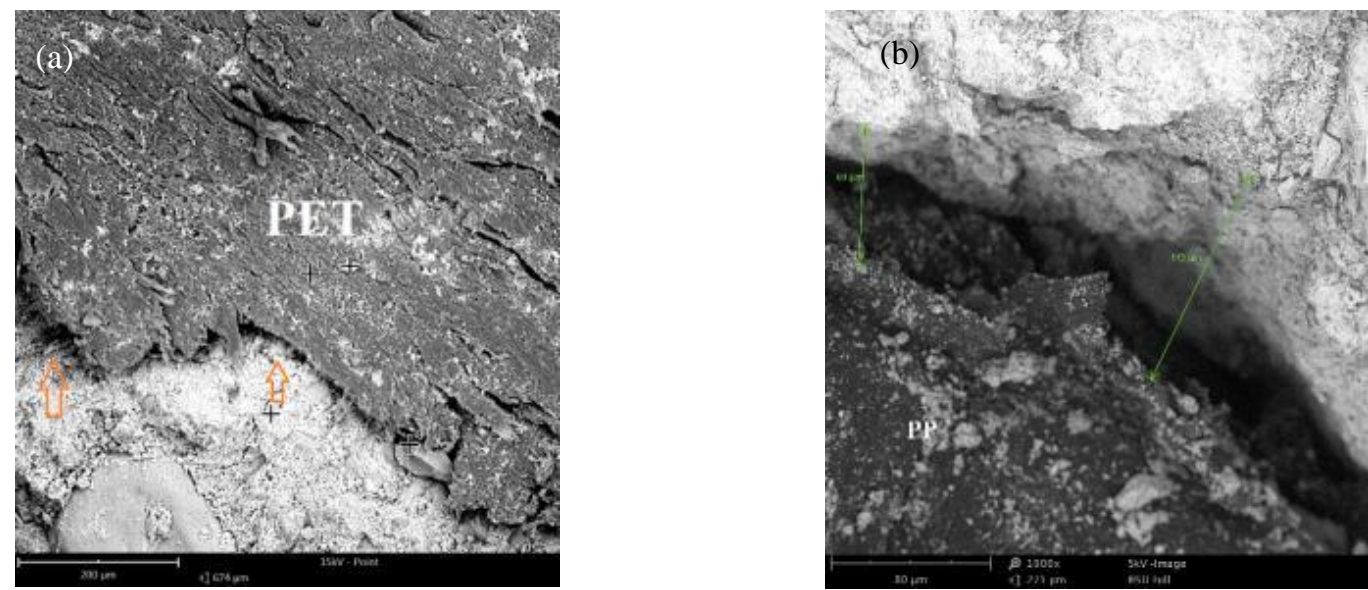

Figure 6: SEM images of surface of concrete with the aggregates: a) PET and b) PP. 
Table 8: Chemical composition at the surface of polymers obtained by EDS.

\begin{tabular}{c|c|c|c|c|c}
\hline \multicolumn{7}{c}{ Chemical composition (\% mass) } \\
\hline Sample & C & $\mathbf{O}$ & Ca & Si & Sb \\
\hline PET & 44.5 & 38.3 & 11.1 & 1.7 & 4.5 \\
\hline PP & 53.1 & 34.3 & 5.8 & 3.7 & - \\
\hline
\end{tabular}

BRAHIM et al. [46] performed similar analysis using SEM images taken from the interfacial zone between PET flakes and concrete matrix. They observed a poor adhesion of PET with the concrete matrix, even though EDS confirmed the presence of hydrated mortar on the surface of the polymer, confirming the results of this study.

Figure 6 (b) shows the SEM image for the concrete containing PP, where a surface with low amount of hydrated calcium silicate crystals can be noted followed by the non-adhesion of the polymer to the cementitious mass. According to some authors [47, 48], this is due to the lower chemical affinity of the polymer to the mortar when compared to natural aggregate and also due to the hydrophobic behaviour of the material which hampers the sodium precipitation at the surface of the polymer. Moreover, the smooth surface of PP does not contribute to the anchorage of the polymer to concrete.

\section{CONCLUSIONS}

The following conclusions can be drawn from the results presented in this work:

- The hygroscopic characteristic of the polymer PET and the shape granules leaded to a lower void content and a lower water absorption when compared to the sample with PP.

- The mixture with PP flakes presented higher modulus of elasticity than the mixture with PET flakes, similar to the reference mixture PP flakes in concrete act as a barrier for the chloride ion penetration, reducing the electric charge passing by less than half of the value for reference mixture.

- In the microscopic analysis it was not possible to verify the adhesion of PET flakes and PP flakes to the concrete.

- The addition of PET flakes presented good results in terms of mechanical properties and some durability issues. However, due to the potential hydrolytic degradation in alkaline environment, the use of PET for structural purpose is not recommended due to the further reduction on the mechanical properties and durability as ageing occurs.

- The addition of PP flakes is considered to be a promising alternative to partially replace sand, due to the good results in terms of mechanical properties and stability in the alkaline environment.

\section{ACKNOWLEDGEMENTS}

The authors acknowledge the "Conselho Nacional de Desenvolvimento Científico e Tecnológico (CNPq)" by granting scholarships and funding the materials that supported this research.

\section{BIBLIOGRAPHY}

[1] ESMAEIL, M.M.Z, MOHAMED, R.K, MAHREZ A, et al. "Using waste plastic bottles as additive for stone mastic asphalt", https://doi.org/10.1016/j.matdes.2011.06.016. Materials and Design, v. 32, pp. 48444849, dez. 2011.

[2] FRIGIONE, M. "Recycling of PET bottles as fine aggregate in concrete", https://doi.org/10.1016/j.wasman.2010.01.030. Waste Management, v. 30, pp. 1101-1106, Jun 2010.

[3] AKÇAÖZOG, L., SEMIHA, A., CENGIZ, D. "An investigation on the use of shredded waste PET bottles as aggregate in lightweight concrete", https://doi.org/10.1016/j.wasman.2009.09.033. Waste Management, v. 30, pp. 285-290, fev. 2010.

[4] FOTI, D, PAPARELLA, F. "Impact behavior of structural elements in concrete reinforced with PET grids", https://doi.org/10.1016/j.mechrescom.2014.02.007. Mechanics Research Communications, v. 57, pp. 57-66. Abr. 2014. 
[5] YANG, S., YUE, X., LIU, X., et al. "Properties of selfcompacting lightweight concrete containing recycled plastic particles", https://doi.org/10.1016/j.conbuildmat.2015.03.038 Construction and Building Materials", v. 84, pp. 444-453, jun. 2015.

[6] NOBILI, A., LANZONI, L., TARANTINO, A.M. "Experimental investigation and monitoring of a polypropylene-based fiber reinforced concrete road pavement",

https://doi.org/10.1016/j.conbuildmat.2013.05.077. Construction and Building Materials, v. 47, pp. 888-895, outb. 2010.

[7] HSIE, M., CHIJEN, T. "Mechanical properties of polypropylene hybrid fiber-reinforced concrete", https://doi.org/10.1016/j.msea.2008.05.037. Materials Science and Engineering, v. 494, pp. 153-157. Outb. 2008.

[8] ALBANO, C., CAMACHO, N., HERNANDEZ, M., et al. "Influence of content and particle size of waste pet bottles on concrete behavior at different w/c ratios", https://doi.org/10.1016/j.wasman.2009.05.007.

Waste Manage, v. 29, pp. 2707-2716. Outb.2009.

[9] FRATERNALI, F., VINCENZO, C.R., ROSARIA, C., et al. "Experimental study of the thermomechanical properties of recycled PET fiber-reinforced concrete",

https://doi.org/10.1016/j.compstruct.2011.03.025. Composite Structures, v. 93, pp. 2368-2374. Aug. 2011.

[10] YERMAK, N.P., PLIYA, A.L., SIMON, A., et al. "Influence of steel and/or polypropylene fibres on the behaviour of concrete at high temperature: Spalling, transfer and mechanical properties",

https://doi.org/10.1016/j.conbuildmat.2016.11.120. Construction and Building Materials, v. 132, 240-250.

Fev. 2017.

[11] GUNCHEOL, L., DONGYEOP, H., MIN-CHEOL, H., et al. "Combining polypropylene and nylon fibers to optimize fiber addition for spalling protection of high-strength concrete",

https://doi.org/10.1016/j.conbuildmat.2012.02.015. Construction and Building Materials, v. 34, pp. 313-320.

Set. 2012.

[12] HAGEWOOD, J. "Technologies for the manufacture of synthetic polymer fibers",

https://doi.org/10.1533/9780857099174.1.48. Advances in Filament Yarn Spinning of Textiles and Polymers, pp. 48-71, 2014.

[13] HALIL L.T., VLASTIMIL K., GREGORIO M., et al. "Higly oriented carbon fiber-polymer composites via addtive manufacturing", https://doi.org/10.1016/j.compscitech.2014.10.009. Composites Science and Technology, pp. 144-150, Dez. 2014.

[14] CORREA, PM. Estudo comparativo da influência da adição de PET e PP pós-consumo na produção do concreto estrutural. Dissertação de Mestrado. Porto Alegre, 2015.

[15] SAIKIA, A., BRITO, J. "Waste polyethylene terephtalateasan aggregate in concrete,"

https://doi.org/10.1590/S1516-14392013005000017. Materials Research,v.16, pp.341-350, Fev. 2013.

[16] ASSOCIAÇÃO BRASILEIRA DE NORMAS TÉCNICAS. NBR 6118: Projeto de estruturas de concreto - Procedimento, Rio de Janeiro, 2018.

[17] RAHMANI, E., DEHESTANI, M.; BEYGI, , et al. On the mechanical properties of concrete containing waste PET particles. Construction and Building Materials. 2013, Vol. 47, pp. 1302-1308.

[18] ASSOCIAÇÃO BRASILEIRA DE NORMAS TÉCNICAS. NBR 16697: Cimento Portland-Requisitos, Rio de Janeiro, 2018.

[19] AMERICAN SOCIETY FOR TESTING AND MATERIALS. ASTM D724: Standard Test Method for Surface Wettability of Paper (Angle-of-Contact Method), 2003.

[20] ASSOCIAÇÃ̃O BRASILEIRA DE NORMAS TÉCNICAS. NBR 5738: Concreto - Procedimento para moldagem e cura de corpos de prova, Rio de Janeiro, 2016.

[21] AMERICAN SOCIETY FOR TESTING AND MATERIALS. ASTM C1202: Standard Test Method for Electrical Indication of Concrete's Ability to Resist Chloride Ion Penetration, 2019.

[22] ASSOCIAÇÃO BRASILEIRA DE NORMAS TÉCNICAS. NBR 9778: Argamassa e concreto endurecidos - Determinação da absorção de água, índice de vazios e massa específica, Rio de Janeiro, 2009.

[23] ASSOCIAÇÃ̃O BRASILEIRA DE NORMAS TÉCNICAS. NBR NM67: Concreto - Determinação da consistência pelo abatimento do tronco de cone, Rio de Janeiro, 1998.

[24] ASSOCIAÇÃO BRASILEIRA DE NORMAS TÉCNICAS. NBR 5739: Concreto - Ensaio de compressão de corpos de prova cilíndricos, Rio de Janeiro, 2018.

[25] ASSOCIAÇÃO BRASILEIRA DE NORMAS TÉCNICAS. NBR 8522: Concreto - Determinação dos módulos estáticos de elasticidade e de deformação à compressão, Rio de Janeiro, 2017.

[26] ASSOCIAÇÃO BRASILEIRA DE NORMAS TÉCNICAS. NBR 9779: Argamassa e concreto endurecidos - Determinação da absorção de água por capilaridade, Rio de Janeiro, 2012.

[27] ARHANT, L.G.M., GAC, P.Y. "Impact of hydrolytic degradation on mechanical properties of PET Towards an understanding of microplastics formation", 
https://doi.org/10.1016/j.polymdegradstab.2019.01.021. Polymer Degradation and Stability, v. 161, pp. 175182. Mar. 2019.

[28] GRAUSE, G., HANDA, T., KAMEDA, T., et al. "Effect of temperature management on the hydrolytic degradation of PET in a calcium oxide filled tube reactor",

https://doi.org/10.1016/j.polymdegradstab.2019.01.021. Chemical Engineering Journal, v.166, pp. 523-528. Marc.2019.

[29] PÉREZ, A., CLIMENT, M., GARCÉS, P. "Electrochemical extraction of chlorides from reinforced concrete using a conductive cement paste as the anode", https://doi.org/10.1016/j.corsci.2010.01.016. Corrosion Science, v. 52, pp. 1576-1581, Maio. 2010.

[30] JHNSTON, C. D. "Fiber-reiforced cement and concrete". In: V. M. MALHORTA. Advances in concrete technology. 2ed. Ottawa: V. M. Malhorta, pp. 603-673, 1994.

[31] FOTI, D. "Use of recycled waste pet bottles fibers for the reinforcement of concrete",

https://doi.org/10.1016/j.compstruct.2012.09.019. Composite Structures, v. 96 pp. 396-404. Fev. 2013.

[32] ROUHOLLAH, R., MOHAMMAD, Z., MANSOOR, M. et al. "The effect of concrete alkalinity on behavior of reinforcing polyester and polypropylene fibers with similar properties",

https://doi.org/10.1016/j.cemconcomp.2018.12.012. Cement and Concrete Composites, v.97 pp. 118-124, Mac. 2019.

[33] AZAD, A., MOHAMMED, A. "Experimental behavior and analysis of high strength concrete beams reinforced with PET waste fiber", https://doi.org/10.1016/j.conbuildmat.2020.118350. Construction and Building Materials. v. 244. Fev. 2020

[34] STROBEL, M., LYONS, C.S., STROBEL, J., et al. "Analysis of air-corona treated polypropylene and poly(ethylene terephthalate) films by contact angle measurements and X-ray photoelectron spectroscopy". https://doi.org/10.1163/156856192X00764. J. Adhesion Sci. Technol, 6, 4, pp. 429-443, Abr. 2012.

[35] WANKE, C.H. "Recuperação hidrofóbica de polipropileno tratado por VUV ou plasma", https://doi.org/10.1590/S0104-14282012005000027. Polímeros, v.22. pp. 158-163, Mai. 2012.

[36] BATAYNEH, M., MARIE, I., E ASI, I. "Use of selected waste materials in concrete mixes", Waste Management. https://doi.org/10.1016/j.wasman.2006.07.026. v. 27, pp. 1870-1876, 2007.

[37] AZAD, A.M. "Modelling the mechanical properties of concrete containing PET waste aggregate", Construction and Building Materials, https://doi.org/10.1016/j.conbuildmat.2017.05.154. v. 244, pp. 595-605,

Set. 2017.

[38] HANNAWI, K., KAMALI-BERNARD, S., PRINCE, W. "Physical and mechanical properties of mortars containing PET and PC waste aggregates", Waste Management, v. 30, Nov. 2010. pp. 2312-2320.

[39] CHOWDHURY, S. "Early age bond strength of reinforcing bars in high strength concrete", Special Session on Structural Solid Mechanics, 4th International Conference on Structural Engineering and Construction Management, 2013.

[40] TREJBAL, L., KOPECKÝ, P.,.TESÁREK, J., et al. "Impact of surface plasma treatment on the performance of PET fiber reinforcement in cementitious composites", https://doi.org/10.1016/j.cemconres.2016.08.018, Cement and Concrete Research, v. 89, pp. 276-287, Nov. 2016.

[41] SAIKIA, N., BRITO, J. "Waste polyethylene terephthalate as an aggregate in concrete", https://doi.org/10.1590/S1516-14392013005000017, Materials Research, v. 16. Fev. 2013.

[42] ROMÃO, W., SPINACÉ, M.A.D.P. "Poli (Tereftalato de Etileno) PET: Uma Revisão Sobre os Processos de Síntese, mecanismos de de degradação e sua reciclagem" https://doi.org/10.1590/S010414282009000200009. Polímeros, v. 19, pp. 121-132, Jun. 2009.

[43] CALLISTER, W.D., Ciência e Engenharia de Materiais: Uma Introdução. John Wiley \& Sons, Inc., 2002.

[44] STUART, B.H. Polymer Analysis. [S.1.]: John Wiley \& Sons, Inc., 2002

[45] CHOI, W., YONG, D.; KIM,Y., et al. "Characteristics of mortar and concrete containing fine aggregate manufactured from recycled waste polyethylene terephthalate bottles", https://doi.org/10.1016/j.conbuildmat.2009.02.036. Construction and Building Materials. v. 23, pp. 28292835, Aug. 2009.

[46] BRAHIM, S., MOHAMMED, S., ADJAMILA, A., et al. "The use of plastic waste as fine aggregate in the self-compacting mortars: Effect on physical and mechanical properties", https://doi:

10.1016/j.conbuildmat.2013.02.049. Construction and Building Materials. v. 43, pp. 436-442, Jun. 2013. [47] BUENDÍA, A.M.L., SÁNCHEZ, M.D.R., CLIMENT, V., et al. "Surface treated polypropylene (PP) fibres for reinforced concrete", https://doi.org/10.1016/j.cemconres.2013.08.004. Cement and Concrete Research, v. 54, pp. 29-35, Dez. 2013. 
[48] FELEKOĞLU, B., TOSUN, K.; BARADAN, B. "Effects of fibre type and matrix structure on the mechanical performance of self-compacting micro-concrete composites", https://doi.org/10.1016/j.cemconres.2009.07.007. Cement and Concrete Research, v. 39, pp. 1023-1032, Nov. 2009.

\section{ORCID}

Priscila Marques Correa

Diego Guimarães

Ruth Marlene Campomanes Santana

Angela Gaio Graeff https://orcid.org/0000-0003-3084-2949

https://orcid.org/0000-0001-9763-0655

https://orcid.org/0000-0001-6843-9915

https://orcid.org/0000-0001-6453-8270 